\title{
Animal Biotelemetry: First anniversary
}

\author{
A Peter Klimley
}

\begin{abstract}
Editorial
The 4th of April marks the first anniversary of the launch of Animal Biotelemetry, and an occasion to thank the scientific community for your support of the journal. We are thankful to the Associate Editors, who sent manuscripts out for review, the editorial board members, who have encouraged their colleagues and students to publish in the journal, and finally the expert reviewers of the articles. The bottom line is that Animal Biotelemetry is built on the foundation of your work, and relies on the support of the scientific community to ensure that it continues to provide a useful resource to researchers in this field.
\end{abstract}

In the first year, the journal has been very well received, publishing 21 original articles and five reviews/editorials. We have published original research articles on the physiology, behavior, and ecology of diverse species ranging from Chinook salmon [1], European silver eels [2], white sharks [3], bluetongue lizards [4] , bowhead whales [5], and brown bears [6]. We also have published a variety of techniques-based articles on ultraviolet radiation for sterilization of surgical tools [7], different types of tissueclosure sutures during tag implantation [8], tag attachment designs [9], and criteria for determining whether a tag has been released and is floating on the surface versus being attached to a whale shark [10]. Articles have also been published on the analysis of telemetry data such as the effect of high detection probabilities on survival models in release-recapture studies [11] and methods for selecting a bandwidth in home-range analyses [12]. In addition to this, reviews have been published on the present, past, and future of freshwater tracking studies [13], tracking studies in India [14], and the use of accelerometer sensors to monitor unseen behaviors [15].

Most articles have been accessed over 1000 times and two articles stand out as being particularly highly accessed. The first is an original research article describing the two-year migration of an adult female white sharks [3] and the second a review of tracking animals in freshwater with electronic tags [13]. The first article has been accessed 12,242 times, while the second 5,399 times.

Correspondence: apklimley@ucdavis.edu

University of California, Davis, One Shields Avenue, Davis, CA 95616, USA
Animal Biotelemetry is a showcase for telemetry-based, original research on the physiology, behavior, and ecology of species. At this single site one can also learn about methods of attachment and effects of tagging on a diversity of species, and locate reviews on the applicability to one's study of a particular sensor, transmitter, or mode of telemetry. It is now truly an international journal with the lead authors of papers published during the first year of the journal's existence from Australia, Canada, Denmark, France, India, Greenland, Norway, Spain, Switzerland, and the United States. In the future, the journal will build on these successes and continue to disseminate our contributions widely thanks to the open access model of the journal. Hence, I encourage all of you to publish the results of your studies in Animal Biotelemetry, where they can be widely read within the research community and beyond.

\section{Competing interests}

The author declares that he has no competing interests.

Received: 27 March 2014 Accepted: 28 March 2014 Published: 4 April 2014

\section{References}

1. Brown RS, Oldenburg EW, Seaburg AG, Cook KV, Skalski JR, Eppard M, Deters KA: Survival of seaward-migrating PIT and acoustic-tagged juvenile Chinook salmon in the Snake and Columbia Rivers: an evaluation of length-specific tagging effects. Anim Biotelemetry 2013, 1:8.

2. Økland F, Thorstad EB, Westerberg H, Aarestrup K, Metcalfe JD: Development and testing of attachment methods for pop-up satellite archival transmitters in European eel. Anim Biotelemetry 2013, 1:3.

3. Domeier ML, Nasby-Lucas N: Two-year migration of adult female white sharks (Carcharodon carcharias) reveals widely separated nursery areas and conservation concerns. Anim Biotelemetry 2013, 1:2.

4. Price-Rees SJ, Brown GP, Shine R: Habitat selection by bluetongue lizards (Tiliqua, Scincidae) in tropical Australia: a study using GPS telemetry. Anim Biotelemetry 2013, 1:7. 
5. Heide-Jørgensen M, Laidre KL, Nielsen NH, Hansen RG, Røstad A: Winter and spring diving behavior of bowhead whales relative to prey. Anim Biotelemetry 2013, 1:15.

6. Mazur R, Klimley AP, Folger K: Implications of the variable availability of seasonal foods on the home ranges of black bears, Ursus americanus, in the Sierra Nevada of California. Anim Biotelemetry 2013, 1:16.

7. Walker RW, Markillie LM, Colotelo AH, Geist DG, Gay ME, Woodley CM, Eppard MB, Brown RS: Ultraviolet radiation as disinfection for fish surgical tools. Animal Biotelemetry 2013, 1:4.

8. Woodley CM, Wagner KA, Bryson AJ, Eppard M: Performance assessment of bi-directional knotless tissue-closure devices in juvenile Chinook salmon surgically implanted with acoustic transmitters. Anim Biotelemetry 2013, 1:9.

9. Økland F, Thorstad EB, Westerberg H, Aarestrup K, Metcalfe JD: Development and testing of attachment methods for pop-up satellite archival transmitters in European eel. Anim Biotelemetry 2013, 1:3.

10. Hearn AR, Green JR, Espinoza E, Peñaherrera C, Acuña D, Klimley A: Simple criteria to determine detachment point of towed satellite tags provide first evidenceof return migrations of whale sharks (Rhincodon typus) at the Galapagos Islands, Ecuador. Anim Biotelemetry 2013, 1:11.

11. Skalski JR, Seaburg AG, Buchanan RA: The effects of high detection probabilities on model selection in paired release-recapture studies in the era of electronic tagging studies. Anim Biotelemetry 2013, 1:12.

12. Kie JG: A rule-based ad hoc method for selecting a bandwidth in kernel home-range analyses. Anim Biotelemetry 2013, 1:13.

13. Cooke SJ, Midwood JD, Thiem JD, Klimley P, Lucas MC, Thorstad EB, Eiler J, Holbrook Ebner BC: Tracking animals in freshwater with electronic tags: past, present and future. Anim Biotelemetry 2013, 1:5.

14. Habib B, Shrotriya S, Sivakumar K, Sinha PR, Mathur VB: Three decades of wildlife radio telemetry in India: a review. Anim Biotelemetry 2014, 2:4.

15. Brown DG, Kays R, Wikelski M, Wilson R, Klimley A: Observing the unwatchable through acceleration logging of animal behavior. Anim Biotelemetry 2013, 1:20.

doi:10.1186/2050-3385-2-6

Cite this article as: Klimley: Animal Biotelemetry: First anniversary. Animal Biotelemetry 2014 2:6.

\section{Submit your next manuscript to BioMed Central and take full advantage of:}

- Convenient online submission

- Thorough peer review

- No space constraints or color figure charges

- Immediate publication on acceptance

- Inclusion in PubMed, CAS, Scopus and Google Scholar

- Research which is freely available for redistribution 